\title{
Counseling Playing Method with Boy-boyan Game for the Development of Self-Regulation in Children Aged 6-8 year
}

\author{
Yayah Haryawati \\ Bimbingan dan Konseling (BK) \\ Universitas Pendidikan Indonesia \\ Bandung \\ yayah.haryawati@upi.edu
}

\author{
Cece Rakhmat \\ Bimbingan dan Konseling (BK) \\ Universitas Pendidikan Indonesia \\ Bandung \\ Cece.rakhmat@yahoo.com
}

\author{
Rijal Assidiq Mulyana \\ Early Childhood Education \\ STAI Al Musaddadiyah Garut \\ rijal.assidiq@stai- \\ musaddadiyah.ac.id
}

\begin{abstract}
The study was conducted to explain the counseling playing method through Boy-boyan game for self-regulation development in children aged 6-8 years. The counseling playing method is a derivation in guidance and counseling studies. The counseling playing method is based on theoretical construct of child centered play therapy from client centered therapy developed by Carl Rogers (1951). The method counseling playing, performs counseling functions by playing. The game that the author took was a Boyboyan game, one type of traditional Sundanese game which is often called kaulinan barudak urang lembur. The self-regulation theory that the author takes is selfregulation theory developed by Greenspan. According to this theory, self-regulation and interest in the environment are important stages in the child's emotional development. The finding of this qualitative study reveals that Boyboyan game can serve as a method counseling playing for children self-regulation development. The existence of the rules of play in Boyboyan game can encourage children self-regulation.
\end{abstract}

Keywords--counseling playing method; boy-boyan game; self regulation

\section{INTRODUCTION}

Children development occurs during their early childhood. It is because during that period children have learning potential that shows their individual potential. Children development and learning can be facilitated, even it can be accelerated upto certain limit through an apropriate counseling treatment. In both development and learning process, children can encounter some problems that need help of another person to handle it. For example, children aged 6-8 years commonly encounter some problems suc as: socially Aggressive (aggressively), Oppose (challenging), Hyperactive (Hyperactivity), the Rejected friends (peer rejected); Shy/reserved (shy/withdrawn); Behave predominates (dominant behavior) and others. Counseling method play boyboyan can be an option for overcoming the problems. This counseling method can overcome the social behavior problems that are not favorable for children development. Boy-boyan, one of Sundanese traditional games, has a clear primary rule. The game is done by two groups in which each group consists of ten people. The tool that is used is the fractional form of roof-tile, Sundanese people call it/gerabah/critical talawengkar, and thr roof-tile is hit by kasti ball. Boy-boyan game can develop the self-regulation, and interest towards the environment for children, because the fun is increased and excitement also contains the values of cooperation, communication, self-control; carefully; patience; precision; seriousness, honesty; sportsmanship and want to share it.

\section{A. Counseling Playing Method}

Counseling playing method is based on theoretical construct of child centered play therapy from client centered therapy developed by Carl Rogers (1951). These construct were applied to working with children through play therapy by Virginia Ax line (1947), a student and college of Rogers. The child-centered approach to play therapy, like clientcentered therapy, is based on process of being with children as opposed to procedure of application. Rogers (1986) summarized the essence of the approach: the person-centered than is primarily a way of being that finds its expression in attitude and behaviors that create growth -producing climate. It is a basic philosophy rather than simply a technique or a model. When this philosophy is lives is help the person expand the development of his or her own capacities. When in it is lived, it also stimulates constructive change in others. It empowers the individual, and when this personal power is sensed, experience shows that is tends to be used for personal and social transformation[1]. Landreth said, the child's behavior in this process is goal directed in an effort to satisfy personal needs as experienced in the unique phenomenal field that for that child constitutes reality[1].

\section{B. Boy-boyan Game}

Boy-Boyan game is one of game traditional. According to Traditional games have something meaning games that 
done based on the norms and hereditary heritage and can provide a sense of satisfaction or pleasure for the offender[2]. According to traditional game is a game that has been done by children on a region traditionally[3]. In the Sudanese is also called kaulinan barudak urang lembur.

Boy-Boyan is a game that uses a ball (usually the size of a baseball) made from paper in a round or baseball shape. This game consists of five up to ten people. Then, the pieces of the roof-tile are collected and stacked as many as $10-15$ pieces. There is only one cat (ucing), a one-bet into the castle Assembly has, as one can convey to destroy. If broken tile have collapsed, the cat then gives to the play was allowed to hit by a throw the ball (kabaledog). If there is a contract, the first player out of the game until all kabalédog allowed by the ball[4].

Boy-boyan game as well called pecah piring that are played in groups. Tools that used is only a ball of cesspool and a shard tile or the like is arranged like a tower[5]. Meanwhile, according to in the game boy-boyan is divided into two groups[6]. The first group played down the split towers precarious from a certain distance. Next the second group must compile back the tower of broken tiles scattered while avoiding shoot the ball from the opposing group

\section{Self Regulation Development}

Morrison said Self-Regulation is the ability to control your emotions and behavior, control your excitement for the construction of a good social relations[7]. Charles worth the ability to control emotion, in positive ways with other problem[7]. Avoid aggressive, actions, and become a selfdirective Lerner. Galinsky argues regulating one's thinking, emotions, and behavior is critical for success in school, work, and life. With self-regulation, someone will be able to organize your thoughts, his emotions and behavior towards success for someone in the school environment, work and life[7].

Define self-regulation from Shonkoff and Phillips as a child's ability to gain control of bodily functions, manage powerful emotion, and maintain focus and attention. The growth of selfregulation is a cornerstone of early childhood development and is visible in all areas of behavior[8].

Regulation yourself in the child age (6-8) is very important because it deals with the efforts of controlling emotions and behaviors so they can adapt to the social environment, either together or other peers. A child who has a good self-regulation can be easily accepted by any environment. Self- regulation as a capital base for the child to achieve success in all her life span in a variety of segments, such as family, school, society and the world of work.

\section{RESEARCH METHODS}

According to Denzin and Lincoln said qualitative research is multi method in focus, involving an interpretive naturalistic approach to its subject matter[9]. This means that qualitative researchers study things in their natural settings, attempting to make sense of or interpretation phenomena in terms of the meanings people bring to them.
Moreover Creswell said points out that "qualitative research is an inquiry process of understanding based on distinct methodological traditions of inquiry that explore a social or human problem[9]. The researcher builds a complex, holistic picture, analyzes words, report detailed views of informants, and conducts the study in a natural setting." A case study investigates phenomena as they exist in one point in time. It deals with describing the present actual condition of subjects or objects of the research, i.e. person, groups, institutions, societies, etc. (Gall, et al, 2003).

In this connection, states case study on term of research process: "a case study is an empirical inquiry that investigates the contemporary phenomenon within its real-life context, especially when the boundaries between phenomenon and context are not clearly evident"[10].

According to Depdikbud explains that case study is a comprehensive study or analysis using various techniques, materials and tools regarding the symptoms or characteristic characteristics of various types of disorder or behavior, both individuals and groups[11].

Case study is a technique of conducting counseling preparation that uses the characteristics of collecting complete data, confidential, scientifically continuous, and data obtained from several parties[12].

According to Depdikbud Dirjen Dikdas dan Umum steps in the implementation of case studies are as follows: 1 . Recognizing symptoms. 2. Make a case description objective, simple, and clear. 3. Learn more about the aspects found to determine the type of problem. 4. Types of problems already grouped, translated by contributing more detailed ideas. 105 . Estimate possible causes of the problem. 6. Estimate possible outcomes and types of assistance provided either direct supervision of a mentor teacher or need case conference or referral case. 7. A framework for determining steps to deal with and uncover cases. 8 . The estimates of the cause of the problem help to learn what kind of information is collected in the techniques or tools used in collecting information or data. 9. Data collection steps primarily look at the type of information or data required such as academic ability, attitude, talents, and interests, either through test techniques or non-test techniques[12].

Thus, in the research conducted, boy-boyan game became a counseling method to development self-regulation of children 6-8 aged years.

\section{CONCLUSION}

A method of counseling play boy-boyan 6-8 years of age for children can be one of the treatments for children development of self regulation. Children who love to play Boy-boyan ballpark motor and highly trained energy stored much less excess can be routed appropriately. Play Boy-boyan has rules that have become the terms already agreed with, and lets the child can follow the rules so that a favorable alignment. The winning children trained to be humble and the 
losing children trained to accept the reality and sportsmanship. Every single session counseling play centered on children by using the method of playing the Boy-boyan, then a counselor together konseli (children) perform together as the evaluation, reflection point to provide reinforcement and appreciation for the role that already $\mathrm{He}$ did. Children have a good selfregulatory very pleasant for anyone, because it can control the negative impulses, thereby, control of body functions, control of high emotion and focus or attention can be maintained properly. Children who refuse, aggressive, subdued, and a host of negative behaviour issues can be reasonably controlled and healthy.

\section{References}

[1] D. S. Sweeney and L. E. Homeyer, The handbook of group play therapy: How to do it, how it works, whom it's best for. JosseyBass, 1999.

[2] J. Barat, "RANCANG BANGUN APLIKASI PERMAINAN TRADISIONAL BEKEL BERBASIS ANDROID."

[3] D. H. Ariffudin and S. C. Y. Hartati, "PENERAPAN MODEL PEMBELAJARAN KOOPERATIF TIPE TEAMS GAMES TOURNAMENT (TGT) UNTUK MENINGKATKAN EFEKTIVITAS PEMBELAJARAN PASSING DALAM PERMAINAN SEPAKBOLA (Studi Pada Siswa Kelas X SMK Negeri Mojoagung Jombang)," J. Pendidik. Olahraga dan Kesehat., vol. 4, no. 1, 2016.

[4] D. A. Anggraini, T. A. Amri, and A. Linggawati, "Penggunaan Komposit Karet Alam-arang Aktif-pasir Cor untuk Mengurangi Kandungan Nitrat dalam Larutannya," J. Online Mhs. Bid. Mat. dan Ilmu Pengetah. Alam, vol. 1, no. 2, p. 11, 2014.

[5] D. Mulyani, "Hubungan kesiapan belajar siswa dengan prestasi belajar," Konselor, vol. 2, no. 1, 2013.

[6] S. M. Agustin and H. N. Muhammad, "PENGARUH AKTIVITAS GERAK PERMAINAN TRADISIONAL TERHADAP KELINCAHAN SISWA."

[7] I. Graef, S. Y. Wahyuningtyas, and P. Valcke, "Assessing data access issues in online platforms," Telecomm. Policy, vol. 39, no. 5, pp. 375-387, 2015.

[8] L. G. Gillespie and N. L. Seibel, "Self-regulation: A cornerstone of early childhood development," YC Young Child., vol. 61, no. 4, p. 34, 2006.

[9] H. Herdiansyah, "Metodologi penelitian kualitatif untuk ilmu-ilmu sosial," Jakarta: Salemba Humanika, 2010.

[10] R. K. Yin, "Case study research: design and methods, Applied social research methods series," Thousand Oaks, CA Sage Publ. Inc. Afacan, Y., Erbug, C.(2009). An Interdiscip. heuristic Eval. method Univers. Build. Des. J. Appl. Ergon., vol. 40, pp. 731-744, 2003.

[11] P. Purwanti, "Studi Kasus Terhadap Upaya Mengatasi Kenakalan Anak Melaluin Penerapan Medel Konseling Behavioristik pada Siswa Kelas V SD Medini Undaan Kudus Tahun Pelajaran 2011/2012." Universitas Muria kudus, 2012.

[12] M. E. Wibowo, "Teknik Bimbingan dan Konseling," Semarang Fak. Ilmu Pendidik. IKIP, 1984. 